\title{
Ethnomedicinal Survey of Plants used in the Treatment of Female Infertility in Chanchaga Niger State, Nigeria.
}

\author{
Idu MacDONALD, Ovuakporie-Uvo OGHALE, Gana Jiya HAUWA
}

\begin{abstract}
An ethno-medicinal survey of plants used to treat female infertility in Chanchaga Local Government Area in Minna, Niger state of Nigeria was conducted for record purpose. Using a structured questionnaire, fifteen herbalists; 8 males and 7 females specialized in female infertility treatment were interviewed in September, 2015. A total of 29 taxa belonging to 26 families with their botanical names, frequency index,
\end{abstract}

preparation of drugs, methods and doses were documented. Most remedies were prepared as infusions or decoctions. All species were harvested from the field when needed by locals. It is advised that careful efforts be made to conserve useful plants by inhabitants of the study area. Younger people should also be encouraged to show interest in the knowledge of traditional medicines.

Keywords: Female infertility, Medicinal plants, Minna, Nigeria.
Idu MacDonald, Gana Jiya Hauwa

Department of Biological Sciences, University of Abuja, PMB 117, FCT, Abuja, Nigeria

Ovuakporie-Uvo Oghale

Department of Plant Biology and Biotechnology, University of Benin, PMB 1154, Benin City, Nigeria.

Corresponding author's:

e-mail: mcdonald.idu@gmail.com

Submitted/Gönderilme: 10.03 .2016 Accepted/Kabul: 17.05.2016

Revised/Düzeltme: 10.05 .2016

\section{Introduction}

Ethnobotany is in the midst of re-emergence. This revival reflects an increasing concern about the disappearance of some rain forest plants and tribal cultures/species (1). According to Anifowoshe and Kalu (2), medicinal plants should be put-in-perspective for regeneration and breeding as earlier researchers report that only about 39\% of Rural Communities in Nigeria have access to modern health care services. The local uses of plants and products in health care are principally much higher in areas with little or no access to contemporary health services $(3,4)$. The practice of herbal medicine is fast becoming recognized in the world of predictable medicine as clinical research, analysis, and quality control are capable of demonstrating the treatment value of herbal medicine (5). Plants still remain the basis for development of contemporary drugs and medical plants have been used for years in daily life to treat diseases all over the world (6).

Many plants/plant extracts have been used as fertility agents in folklore and traditional medicines without producing ostensive noxious effects $(7,8)$. Infertility is a major problem heart-rending people medically and physiologically (9). The management alternatives available for the treatment of infertility in males include the use of drugs and variety of 
surgical procedures (10). The gradual shift to herbal therapy makes the herbal practitioners lay claims to have cure to innumerable ailments including infertility, irrespective of ethnology of such diseases (11). A large number of plants have been tested throughout the world for the possible fertility properties (12). Some medicinal plants are extensively used as aphrodisiac to relieve sexual dysfunction, or as fertility enhancing agents. They provide a boost of nutritional value; improving sexual performance and libido $(13,14)$.

Female infertility affects an estimate of 48 million women with the premier incidence in South Asia, Sub-Saharan Africa/Middle East, and Central/Eastern Europe and Central Asia (15). In Nigeria, $60 \%$ of female diseases are infertilityrelated (16). This study was carried out to source information from herbal medicine practitioners specialized in handling female infertility among the people of Chanchaga Local
Government Area in Minna, with a view of documenting them for possible chemical and biological screening of the identified plant in subsequent researches.

\section{Materials and Methods}

\section{Study area}

This survey was carried out in Chanchaga Local Government Area in Minna, Niger State, Nigeria. Minna is the capital city of Niger State in west central Nigeria. This State lies between the latitude of 3.20' east and longitude 8' and 11.3' north. It is bordered to the north by Sokoto State, west by Kebbi State, south by Kogi and south-west by Kwara State. Kaduna and Federal Capital Territory border the State to both north-east and south-east respectively. $85 \%$ of the State's populace is into farming. Chanchaga is one of the twenty five local government areas of Niger state.

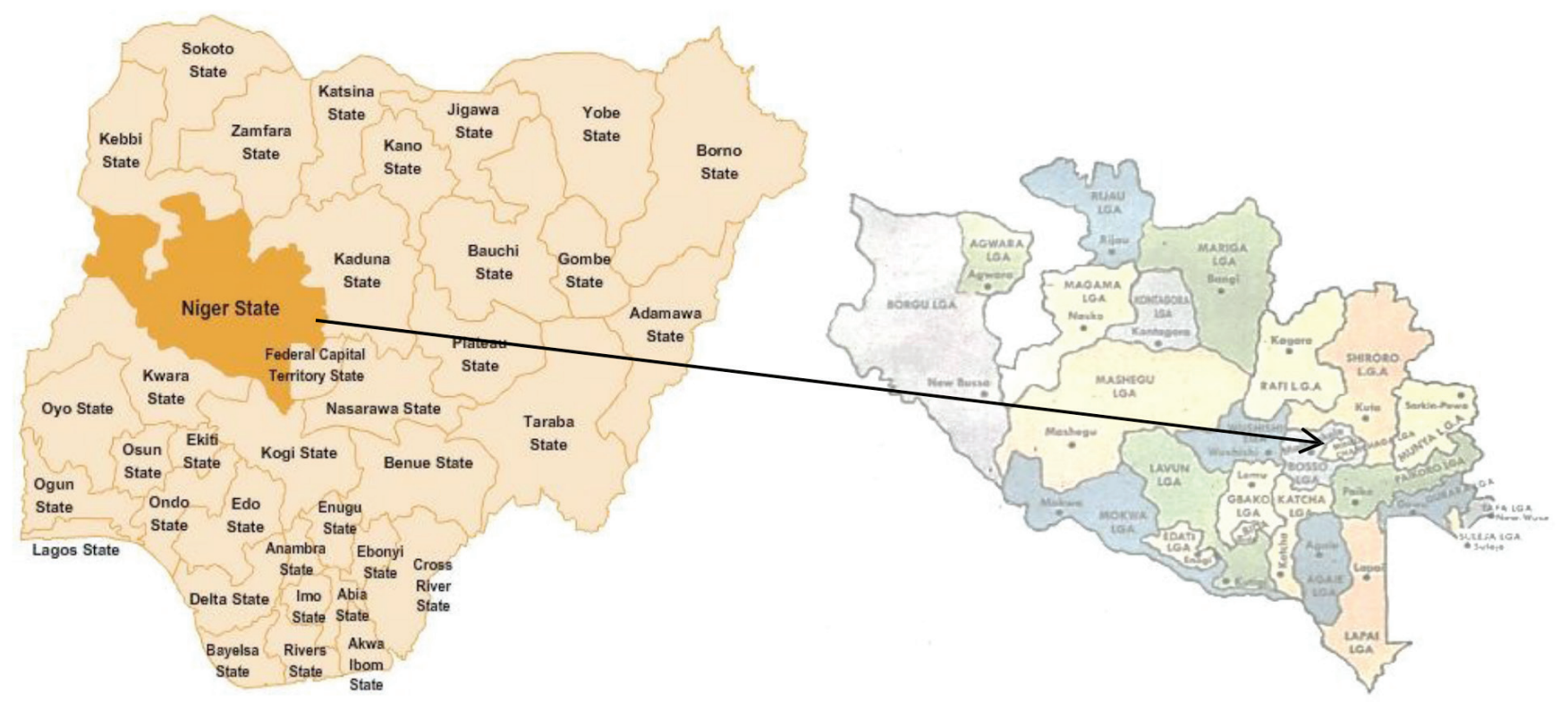

Figure 1. Map of Minna, Niger State in Nigeria.

Data collection: Ethno-medicinal data were obtained by oral interview of fifteen knowledgeable herbal practitioners; eight males and seven females in the study area using a structured questionnaire. Botanical names, common names, vernacular or local names of the various plant species, folk use and method of remedy preparation were chronicled.

Plant identification: Plant identification was partly carried out on the field using some texts useful for plant identification (17-19). All plants surveyed and collected were cross-checked Online to confirm their names and match their photographs. Voucher specimens of collected Plants were deposited and given voucher numbers in the University of Abuja herbarium.

\section{Data analysis:}

Information gathered from the structured questionnaires was tabulated and analyzed using descriptive statistics using Microsoft excel computer software package. The frequency index for each plant was calculated using the following formula:

Frequency index $=\mathrm{n} / \mathrm{N}$ x 100 
Where, ' $n$ ' is total number of practitioners who listed a particular plant species and ' $\mathrm{N}$ ' is total number of interviewed (female infertility inclined herbal) practitioners (20).

\section{Result}

Findings from this survey are a compendium of medicinal plants used for handling female infertility in Minna, Niger State, Nigeria. A total of 29 taxa belonging to 26 families were identified for the treatment of female infertility as reported on Table 1.

Table 1. Medicinal plants used in the treatment of female infertility in Minna, Niger State.

\begin{tabular}{|c|c|c|}
\hline Botanical name & Local name & $\begin{array}{l}\text { Frequency } \\
\text { index }\end{array}$ \\
\hline $\begin{array}{l}\text { Aframomum melegueta } \mathrm{K} \text {. } \\
\text { (Zingiberaceae) }\end{array}$ & $\begin{array}{l}\text { Ose-orji(Y), } \\
\text { Kumfa }(\mathrm{H})\end{array}$ & 80 \\
\hline $\begin{array}{l}\text { Allium sativum L. } \\
\text { (Amaryllidaceae) }\end{array}$ & Tafarunua $(\mathrm{H})$ & 40 \\
\hline $\begin{array}{l}\text { Annona senegalensis Pers. } \\
\text { (Annonaceae) }\end{array}$ & $\begin{array}{l}\text { Nungberechi(N), } \\
\text { Gwandaraj(H) }\end{array}$ & 33.3 \\
\hline $\begin{array}{l}\text { Anogeissus leiocarpus } \\
\text { (DC) Guill \& Perr.( } \\
\text { Annonaceae) }\end{array}$ & $\begin{array}{l}\operatorname{Marike}(\mathrm{H}), \\
\operatorname{Shici}(\mathrm{N})\end{array}$ & 46.7 \\
\hline $\begin{array}{l}\text { Capparis brassii DC. } \\
\text { (Capparaceae) }\end{array}$ & $\begin{array}{l}\text { Gudai }(\mathrm{H}) \text {, } \\
\text { Ekanchi- } \\
\text { wuriagi(N) }\end{array}$ & 26.7 \\
\hline $\begin{array}{l}\text { Citrus aurantifolia } \\
\text { (Christm.) Swingle. } \\
\text { (Rutaceae) }\end{array}$ & Lemunoisami $(\mathrm{H})$ & 53.3 \\
\hline $\begin{array}{l}\text { Corchorus olitorius L. } \\
\text { (Malvaceae) }\end{array}$ & $\begin{array}{l}\operatorname{Ewedu}(\mathrm{Y}) \\
\operatorname{ayoyo}(\mathrm{N}) \\
\text { Ayoyo }(\mathrm{H})\end{array}$ & 46.7 \\
\hline $\begin{array}{l}\text { Cocos nucifera L. } \\
\text { (Arecaceae) }\end{array}$ & $\operatorname{Kwakwa}(\mathrm{H})$ & 66.7 \\
\hline $\begin{array}{l}\text { Combretum apiculatum } \\
\text { Subsp. (Combretaceae) }\end{array}$ & $\begin{array}{l}\text { Farar geeza }(\mathrm{H}) \text {, } \\
\text { Kukunci(N) }\end{array}$ & 60 \\
\hline $\begin{array}{l}\text { Croton penduliflorus } \\
\text { Hutch. (Euphorbiaceae) }\end{array}$ & $\begin{array}{l}\text { Gasay }(\mathrm{H}) \text {, } \\
\text { Aworoso/ } \\
\text { Awogba(Y) }\end{array}$ & 53.3 \\
\hline $\begin{array}{l}\text { Detarium microcarpum } \\
\text { Guill \& Perr. (Fabaceae) }\end{array}$ & $\begin{array}{l}\text { Iyede }(\mathrm{Y}), \operatorname{Tura}(\mathrm{H}) \text {, } \\
\text { Gungoroci }(\mathrm{N})\end{array}$ & 46.7 \\
\hline
\end{tabular}
$\begin{array}{ll}\text { Garcinia kola Heckel. } & \text { Namijin goro(H), } \\ \text { Orogbo(Y) }\end{array}$

(Guttiferae)

60

Juglans regia $\mathrm{L} . \quad \operatorname{Ukpa}(\mathrm{Y})$,

40

(Juglandaceae)

Khaya senegalensis (Desr.) Rimin sauri(H),

60

A Juss. (Meliaceae)

Wuci(N)

Mangifera indica L. Mangwaro(H),

33.3

(Anacardiaceae)

mangoro(Y)

Momordica charantia L.

(Cucurbitaceae)

Daddaagu $(\mathrm{H})$,

Ejinrin (Y)

Moringa oleifera Lam. Jogale (H)

46.7

(Moringaceae)

Newbouldia laevis

Dinberechiamille

(P.Beauv) (Bignoniaceae) (N),

Aduruku (H)

Nicotiana tabacum L. Taba(H)

46.7

(Solanaceae)

Sarcocephalus latifolius Gbashi(N),

(Sm) E.A. Bruce

(Combretaceae)

Tatashiya(H)

Sesamum indicum L. $\quad \operatorname{Ridi}(\mathrm{H})$, eluru(Y)

40

(Pedaliaceae)

Syzygium aromaticum Konafuru(Y)

80

(L.) Merrill \& Perry

(Myrtaceae)

Sorghum bicolor L.

Moench (Poaceae)

Parsnars spp.

(Caesalpinaceae)

Parinari polyandra Benth. Gwanjan kusa(H)

(Chrysobalanaceae) Abaddima(N)

Terminalia avicennioides $\quad \mathrm{Kpace}(\mathrm{H})$,

Guill \& Perr. Baushe $(\mathrm{H})$

40

(Combretaceae)

Tetrapleura tetraptera $\quad \operatorname{Aidan}(\mathrm{Y})$,

(Schum \& Thonn.)

(Mimosaceae)

Wuyan giwa $(\mathrm{H})$,

arida $(\mathrm{N})$

Vitellaria paradoxa Kadanya $(\mathrm{H})$,

73.3

Gaertn. F (Sapotaceae)

Vernonia amygdalina Del. (Asteraceae)
Tsula $(\mathrm{N})$, Shiwaka(H) 
Observation from this work also showed that the herbalists in the knowledge of herbal treatment for female infertility were aged 40 and above. Table 2 shows the basic six recipes (plants/ combination of plants) used in the treatment of female infertility, the plant parts used for preparing the recipes, the modes of preparation and usage of these recipes

Table 2. Preparation of Various Remedies/ Recipes for Handling Infertility in Minna, Niger State.

\begin{tabular}{|c|c|c|c|c|}
\hline Recipes & $\begin{array}{l}\text { Plants/ Plant } \\
\text { combinations } \\
\text { (Botanical } \\
\text { names) }\end{array}$ & $\begin{array}{l}\text { Plant } \\
\text { parts } \\
\text { used }\end{array}$ & $\begin{array}{l}\text { Mode of } \\
\text { preparation } \\
\text { and usage }\end{array}$ & Dosages \\
\hline A & $\begin{array}{l}\text { Tetrapleura } \\
\text { tetraptera, } \\
\text { Mangifera } \\
\text { indica L., } \\
\text { Syzygium } \\
\text { aromaticum, } \\
\text { Allium } \\
\text { sativum, }\end{array}$ & $\begin{array}{l}\text { Seeds, } \\
\text { bark, } \\
\text { seed, } \\
\text { bulbs, } \\
\text { straw } \\
\text { and } \\
\text { bark }\end{array}$ & $\begin{array}{l}\text { Decoction; } \\
\text { The plant } \\
\text { materials } \\
\text { are boiled } \\
\text { together in } \\
2 \text { Liter of } \\
\text { clean water } \\
\text { for } 1 \text { hour }\end{array}$ & $\begin{array}{l}\text { The cooled } \\
\text { solution } \\
\text { drunk: } 250 \\
\text { ml is taken } \\
\text { morning } \\
\text { and evening } \\
\text { for } 2 \text { weeks. }\end{array}$ \\
\hline
\end{tabular}

Sorghum bicolor, Khaya senegalensis

B

\begin{tabular}{|c|c|c|c|}
\hline $\begin{array}{l}\text { Vernonia } \\
\text { amygdalina, } \\
\text { Citrus } \\
\text { aurantifolia }\end{array}$ & $\begin{array}{l}\text { Leaves, } \\
\text { juice } \\
\text { from } \\
\text { fruit }\end{array}$ & $\begin{array}{l}\text { Infusion; } \\
\text { Squash } \\
\text { the leaf of } \\
\text { Vernonia } \\
\text { amygdalina } \\
\text { with the } \\
\text { juice from } \\
\text { Citrus spp. } \\
\text { and separate } \\
\text { the extract. }\end{array}$ & $\begin{array}{l}\text { One glass } \\
\text { cup of the } \\
\text { preparation } \\
\text { daily for } 2 \\
\text { weeks. }\end{array}$ \\
\hline
\end{tabular}

$\begin{array}{llll}\begin{array}{lll}\text { Momordica } \\ \text { charantia }\end{array} & \text { Leaves } & \text { Infusion; } & \text { One tea } \\ & \text { and } & \text { Extract } & \text { spoonful to } \\ & \text { fruits } & \text { macerated } & \text { be taken 3 } \\ & & \text { from fresh } & \text { times daily } \\ & & \text { Leaves and } & \text { for 1 month. } \\ & & \text { Fruit } & \end{array}$

D

$\begin{array}{llll}\begin{array}{l}\text { Combretum } \\ \text { apiculatum, } \\ \text { Sarcocephalus }\end{array} & \begin{array}{l}\text { Roots, } \\ \text { roots }\end{array} & \begin{array}{l}\text { Decoction; } \\ \text { Wash roots }\end{array} & \begin{array}{l}\text { One glass } \\ \text { cup is taken } \\ \text { every }\end{array}\end{array}$

\begin{tabular}{|c|c|c|c|c|}
\hline & Latifolius & & $\begin{array}{l}\text { properly to } \\
\text { avoid dirt, } \\
\text { Boil the two } \\
\text { plant parts } \\
\text { together with } \\
\text { clean water for } \\
30 \text { minutes }\end{array}$ & $\begin{array}{l}\text { morning } \\
\text { for } 2 \\
\text { weeks. }\end{array}$ \\
\hline $\mathbf{E}$ & $\begin{array}{l}\text { Parsnars } \\
\text { spp., Croton } \\
\text { penduliflorus, } \\
\text { Citrus } \\
\text { aurantifolia }\end{array}$ & $\begin{array}{l}\text { Seeds, } \\
\text { seeds, } \\
\text { juice } \\
\text { from } \\
\text { fruits }\end{array}$ & $\begin{array}{l}3 \text { pieces } \\
\text { of Abeere } \\
\text { crushed and } \\
\text { mix with lime. } \\
3 \text { pieces of } \\
\text { Aworoso seed, } \\
\text { crushed soak } \\
\text { for } 3-4 \text { hrs in } \\
\text { water or mix } \\
\text { with pap. }\end{array}$ & $\begin{array}{l}\text { Dosage: } \\
\text { One tea } \\
\text { spoonful is } \\
\text { taken after } \\
\text { meal for } 1 \\
\text { week. }\end{array}$ \\
\hline $\mathbf{F}$ & $\begin{array}{l}\text { Garcinia kola, } \\
\text { Sesamum } \\
\text { indicum }\end{array}$ & $\begin{array}{l}\text { Seeds, } \\
\text { seeds }\end{array}$ & $\begin{array}{l}\text { Infusion; } \\
\text { Garcinia } \\
\text { kola (seed) is } \\
\text { crushed and } \\
\text { tincture made } \\
\text { with gin or } \\
\text { fresh palm } \\
\text { wine. The } \\
\text { Sesamum } \\
\text { indicum are } \\
\text { eaten. }\end{array}$ & $\begin{array}{l}\text { Two shot } \\
\text { thrice } \\
\text { daily, } \\
\text { Sesamum } \\
\text { indicum } 2 \\
\text { or } 3 \text { pieces } \\
\text { eaten twice } \\
\text { daily for } 7 \\
\text { days. }\end{array}$ \\
\hline G & $\begin{array}{l}\text { Citrus } \\
\text { aurantifolia }\end{array}$ & $\begin{array}{l}\text { Juice from } \\
\text { fruits }\end{array}$ & $\begin{array}{l}\text { Lime juice } \\
\text { is mixed } \\
\text { with honey. }\end{array}$ & $\begin{array}{l}\text { Taken twice } \\
\text { daily for } \\
\text { two weeks. }\end{array}$ \\
\hline
\end{tabular}

This study reports 29 taxa used in the management of female infertility in Chanchaga Local Government Area in Minna, Niger State. The most cited family was Combretaceae and the species were Combretum apiculatum (60\%), Sarcocephalus latifolius (40\%) and Terminalia avicennioides (33.3\%). In previous findings, decoctions of Combretum apiculatum leaves have been reported useful as an enema to relieve stomach disorders and to treat conjunctivitis (21). Newbuoldia laevis commonly referred to as 'Tree of life' is a multi-useful plant. In this study, all

15 herbal practitioners interviewed use its leaves in preparing recipes for female infertility remedies (100\%) (Table1). A decoction of Newbuoldia laevis roots in synergy 
with the roots of Alstonia boonei, Jatropha curcas are used to treat epilepsy (22). The stem bark with clay and red pepper is also used against pneumonia, fever, cold and cough (23).

The difference in species richness, diversity, abundance and similarity of species across communities is indicative of varying levels of awareness and knowledge of the plants medicinal use. This statement corroborates with findings in this study. Modernization has impacted deleteriously on the conservation of traditional knowledge on herbal remedies hence, most indigenous information are lost (24). Moreover, deaths of aged traditional healers have contributed to the observed decline in knowledge of traditional treatment for many diseases of man (25).

All 29 taxa found useful in traditional management of female infertility in Chanchaga LGA are often harvested from the wild without control. This practice corroborates with research report of Soladoye et al., (26) who stressed on the need to introduce controlled access to the collection of useful plant species from the wild. To this end, urgent conservation measures must be taken to obviate degradation of the ecosystems where these medicinal plants thrive naturally. From information gathered from the questionnaires, seeds and leaves were the most plant parts used in handling female infertility. The fifteen respondents consisted of 8 males and 7 females between the ages of 40-50 years old. This tells

Nijerya'nın Nijer eyaletinde bulunan Chanchaga bölgesinde, kadınlarda kısırlık tedavisi için kullanılan bitkiler üzerinde etno-medisinal bir araştırma

ÖZ

Nijerya’nın Nijer eyaletinde bulunan Minna yöresi Chanchaga yerel yönetimler bölgesinde, kadınlarda kısırlık için kullanılan bitkilerin kayıt altına alınması amacıyla bir etno-medisinal araştırma gerçekleştirilmiştir. $\mathrm{Bu}$ amaçla yapılandırılmış anket formları kullanılarak, kadınlardaki kısırlığın tedavisinde deneyimli,7'si erkek ve 8'i kadın olmak üzere toplamda 15 aktar ile görüşülmüştür. Toplamda 26 familyaya ait 29 taksonun

\section{REFERENCES}

[1] Soladoye MO, Chukwuma EC, Owa FP. An 'Avalanche' of Plant Species for the Traditional Cure of Diabetes mellitus in South-Western Nigeria. J Nat Prod Plant Res 2012; 2:60-72.

[2] Anifowoshe EI, Kalu C. Ethnomedical Uses of Plants among the Ekitis in Irepodun/Ifelodun Local Government Area, Ekiti State. J Tropical Agric Res 2003; 6:69-73.

[3] Saeed M, Arshad M, Ahmad E, Ishaque M. Ethnophytotherapies for the Treatment of Various Diseases by the Local People of Selected Areas of N. W. F. P. Pakistan J Biol Sci 2004; 7:1104-8. that the younger generations need to show more interest in ethno-medicinal practices as earlier advocated by Sani and Aliyu (27) and Monali et al. (28). From Table 2, we see that all except recipes $\mathrm{C}$ and $\mathrm{G}$ are a combination of more than one plant working synergistically to produce their said biological effect; a phenomenon supported by the research report of Aqil et al. (29) and Akil Hossain et al. (30).

This study in summary has provided a record of plants used in handling female infertility by the indigenes of Chanchaga LGA in Minna. The documentation and publication of these findings will ensure the preservation of indigenous knowledge and use of these medicinal plants. The subject matter of conservation cannot be down-played. Thus, useful plants should be cultivated by all means by indigenes of various localities where their therapeutic uses are harnessed to ensure sustainable use.

\section{Conclusion}

Female infertility is a home-breaker in many countries of the world including Nigeria. It is eminent to seek solution to female infertility all ways possible including herbal approach. Plants documented should be further researched to confirm the claims of herbal practitioners in this study. Much emphasis may be placed on the plants with higher frequency index.

botanik adları, yerel adları, frekans indisi, ilaçların hazırlanışı, yöntemleri ve dozları kaydedilmiştir. Çoğu ilaçlar, infüzyon veya dekoksiyonları olarak hazırlanmaktadır. Bütün türler, yerliler tarafından ihtiyaç duyulduğunda araziden toplanmaktadır. Faydalı bitkilerin toplanması sırasında korunması için dikkat ve gayret gösterilmesi gerektiği konusunda yerli halka tavsiyede bulunulmuştur. Genç insanlar, geleneksel ilaçlarla ilgili bilgilere itibar etmeleri için teşvik edilmelidirler.

Anahtar kelimeler: Kadın kısırlı̆̆ı, tıbbi bitkiler, Minna, Nijerya.
[4] Idu M, Erhabor JO, Ovuakporie-Uvo O. Am J Ethnomed 2014; 1:072-088.

[5] Soladoye MO, Chukwuma EC, Sulaiman OM, Feyisola RT. Ethnobotanical Survey of Plants Used in the Traditional Treatment of Female Infertility in Southwestern Nigeria. Ethnobot Res Appl 2014;12: 081-090.

[6] Ates DA, Erdogrul OT. Antimicrobial Activities of Various Medicinal and Commercial Plant Extracts. Turk J Bio 2003; 27: 157-62.

[7] Sharma JD, Sharma L, Yadav P. Antifertility Efficacy of 
Piper Betle Linn. (Petiole) on Female Albino Rats. Asian J Exptl Sci 2007; 21:145-50.

[8] Singh A, Singh, SK. Evaluation of Antifertility Potential of Brahmi in Male Mouse. Contraception 2009; 79:71-9.

[9] Akomolafe SF, Oboh G, Akindahunsi AJ, Akinyemi OA. Inhibitory Effect of Aqueous Extract of Moringa oleifera And Newbouldia laevis Leaves on Ferrous Sulphate Sodium Nitroprusside Induced Oxidative Stress in Rat's Testes In Vitro. Open J Med Chem 2012; 2:119-28.

[10] Jungwirth A, Diemer T, Dohle GR, Giwercman A, Kopa Z, Krausz C, Tournaye H. Guidelines on Male Infertility. Eur Assoc Urol 2015:1-42

[11] Anthony BO, Oladipupo AL, Adedoyin KL, Tjuddin IA. Phytochemistry And Spermatogenic Potentials of Aqueous Extract of Cissus populnea (Guill. and Per) Stem Bark. Sci World J 2006; 6:2140-6.

[12] Bhatia DK, Sharma AK, Pathania PC, Khanduri NC. Antifertility Effects Of Crude Different of Adiantum lunulatum Burn. on Reproductive Organs of Male Albino Rats. Biol Forum-An Intl J 2010; 2:88-93.

[13] Yakubu MT, Akani MA, Oladiji AT. Male Sexual Dysfunction and Methods Used in Assessing Medical Plants with Aphrodiasiac Potentials. Pharma Rev 2007; 1:49-56.

[14] Semenya SS, Potgieter MJ. Ethnobotanical survey of medicinal plants used by Bapedi traditional healers to treat erectile dysfunction in the Limpopo Province, South Africa. J Med Plants Res 2013; 7:349-57.

[15] Mascarenhas MN, Flaxman SR, Boerma T, Vanderpoel S, Stevens GA. National, Regional, and Global Trends in Infertility Prevalence Since 1990: A Systematic Analysis of 277 Health Surveys. PLOS Med 2012; 9:e1001356.

[16] Ojeme V. "Infertility in Nigeria at 60\% - Gynaecologist" Vanguard Media Limited, Nigeria. 2011. Available online: http://www.vanguardngr.com/2011/06/infertility-in-nigeriaat-60-gynaecologist/. [accessed $10^{\text {th }}$ March, 2016].

[17] Akobundu IO, Agyakwa CW. A Handbook of West African Weeds. International Institute of Tropical Agriculture. Ibadan. 1998, pp 564.

[18] Ayensu ES. Medicinal Plants of West Africa. Reference Publication Inc, Michigan, USA. 1978.

[19] Keay RWJ. Trees of Nigeria. Clarendon Press. Oxford, USA. 1989, pp 476.

[20] Dharmadasa RM, Akanlanka GC, Muthukumarana
PRM, Wijesekara RGS. Ethnopharmacological survey on medicinal plants used in snakebite treatment in Western and Sabaragamuwa provinces in Sri Lanka. J Ethnopharmacol 2016; 179: 110-27.

[21] Coates PM. Keith Coates Palgrave Trees of Southern Africa $3^{\text {rd }}$ edn. Struik Cape Town. 2002. Available at; www. namibiana.de [accessed $10^{\text {th }}$ March, 2016].

[22] Adodo A. Nature Power A Christian Approach to Herbal Medicine, $3^{\text {rd }}$ edition. Generation Press Limited. Lagos. 2004, pp290.

[23] Idu M, Akinnibosun AH, Omohimin CA, Ejale A. Ethnomedicinal field study in the wetlands of Udu and Ughievwan clans of Delta State, Nigeria. Proceedings of Global Summit on Medicinal Plants 2003; 1:98-106.

[24] Okello DK, Biruma M, Deom CM. Overview of Groundnuts Research in Uganda: Past, Present and Future. Afr J Biotechnol 2010; 9: 6448-59.

[25] Chima UD, Ofodile EAU, Okorie MCF. A Survey of Plants used in the Treatment of Ante- Natal and Post-Natal Disorders in Nneochi Local Government Area of Abia State, Nigeria. Greener J Biol Sci 2013; 3:229-37.

[26] Soladoye MO, Chukwuma EC, Yakubu FP, Kola-Oladiji K, Alabi DA, Agbomeji YO. The Collection, Conservation of Medicinal Plants for Natural/Medicine Production. Paper Presented at the Seminar/Workshop and Exhibition of Natural Medicine Association, Ijebu-North, and Faculty of Science, Olabisi Onabanjo University, Ago-Iwoye, Nigeria. $19^{\text {th }}-23^{\text {rd }}$ September, 2006.

[27] Sani HD, Aliyu BS. A Survey of Major Ethno Medicinal Plants of Kano North, Nigeria, Their Knowledge and uses by Traditional Healers. Bayero J Pure Appl Sci 2011; 4:28 -34.

[28] Monali G, Bijayalaxmi D, Dash NC. Traditional Method of Reproductive Health Care Practices and Fertility Control among the Bhumija Tribe of Baleswar, Orissa. Ethno Med 2011; 5:51-5.

[29] Aqil F, Ahmad I, Owais M. Evaluation Of Anti-MethicillinResistant Staphylococcus aureus (MRSA) Activity and Synergy of Some Bioactive Plant Extracts. J Biotech 2006; 1:1093-1102.

[30] Akil Hossain M, Park J, Kim J, Suh J, Park S. Synergistic Effect and Antiquorum Sensing Activity of Nymphaea tetragona (Water Lily) Extract. Biomed Res Intl 2014; 2014:1-4. 